\title{
Egalitarian Parental Care: Literature Review and Conceptual Construction
}

\author{
Carine Valéria Mendes dos Santos* (D), Nathalia Teixeira Caldas Campana (D), \\ \& Isabel Cristina Gomes (D)
}

Universidade de São Paulo (USP), São Paulo, SP, Brasil

\begin{abstract}
This literature review discusses how the concept of egalitarian parental care is constructed as a representation of the new dynamic in parents/children relations in the contemporary world. To achieve this goal, it retrieves national and international scientific publications in the last five years and focus, as a matter of priority, on the psychological perspective. Results were presented according to data distribution between areas of knowledge, methods, international and national occurrence. Analysis was based on the following categories: assumptions for an ideal egalitarian family, contemporary parenting, parenting versus work versus professional career, and egalitarian parental care. Conclusion shows that egalitarian parental care is a trend in contemporary parenthood construction and demand further investigation in diverse contexts.
\end{abstract}

KEYWORDS: parenthood, family, egalitarian relations, gender relations, psychology

\section{Cuidado Parental Igualitário: Revisão de Literatura e Construção Conceitual ${ }^{* * * * * *}$}

\begin{abstract}
RESUMO - Esta revisão de literatura tem o objetivo de, por meio do levantamento da produção científica nacional e internacional dos últimos cinco anos, discutir a construção do conceito cuidado parental igualitário, enquanto representação de uma nova dinâmica de funcionamento da relação pais/filhos(as) na contemporaneidade, priorizando o enfoque da Psicologia. Os resultados serão apresentados em função da distribuição da produção por: áreas de estudo, metodologias utilizadas, incidência mundial e incidência nacional. O corpus de análise foi aprofundado em torno das categorias: pressupostos para um ideal igualitário de família; parentalidade contemporânea; parentalidade versus trabalho versus carreira profissional; e cuidado parental igualitário. Conclui-se que o cuidado parental igualitário constitui uma tendência na construção da parentalidade contemporânea que demanda maiores investigações em contextos diversificados.
\end{abstract}

PALAVRAS-CHAVE: parentalidade, família, relações igualitárias, relações de gênero, psicologia

In the contemporary context the family is undergoing significant changes that simultaneously affect what we here call as constitutive and relational dimensions of the family structure. As regards the constitutive dimension, there is an increasing expansion of the limits of what has been considered as family, with the inclusion of families affectively constituted, in addition to those biologically assured. This is the case with single-parent, reconstituted, homoparenting, co-parental (parental sharing to raise children in gay and lesbian couples) families, childless couples (Araújo, 2011; Corrêa, 2012; Grossi, 2003), and the artificial family whose nucleus encompasses a biological mother (mother who "borrows" the uterus or donates eggs) exercising substitute motherhood and the biological father

\footnotetext{
* E-mail: carinevmendes@gmail.com

**This article was translated with the support of the São Paulo Research Foundation (FAPESP), Proceeding 2018/13403-0.

***Work derived from the thesis written by the first and the second authors, advised by the third: "Egalitarian parental care: repercussions on the construction of a triadic father-mother-baby interaction model” (Funding: São Paulo Research Foundation [proceeding $\mathrm{n}^{\circ}$ 2015/24335-7]) and "A study on contemporary parenting and the early childhood network of care” (Funding: São Paulo Research Foundation [proceeding ${ }^{\circ}{ }^{2015 / 03045-0]) . ~}$ - Submetido: 27/12/2016; Revisado: 07/09/2017; Enviado: 03/10/2017.
} 
(father who donates sperm) responsible for genetic paternity, in addition to the social mother and father responsible for the primary care of the child (Gradvohl, Osis, \& Makuch, 2014).

In the relational dimension, the family presents changes in the organization of the positions of the members and in the flexibility with which these positions have been occupied by the parental figures. From the relations previously governed by a hierarchical and dichotomous system that valued male and paternal power and authority, we now perceive an organization with a tendency towards horizontalization of relations in view of democratic and egalitarian ideals in the mediation of roles and functions between fathers and mothers (Araújo, 2011).

The change on relational flexibility would be due to the possibility of parental organization to be presented interchangeably, regardless the gender of each caregiver, which would allow enhancing the capacity of negotiation, and decreasing the incidence of stereotypes in the guiding of parenting practices. This flexibility is also extended to the possibility of more parent-child negotiations, as children are no longer educated under the imposition of undisputed and preconceived authority, but for the respect for an authority intrinsically linked to the affective intimacy constructed (Rodriguez \& Gomes, 2012).

These changes, however, occur progressively and with a level of complexity still barely intelligible. Some of the factors that foster and consolidate this context include: feminism as an element of mobilization and resignification of women's social and political rights and access; the contraceptive pill and dissociation between sexuality and procreation; the massive entry of women in the labor market; women's access to better educational opportunities; divorce as a possibility; the decline of patriarchal authority; the insertion of men in the domestic environment as caregivers of children and helpers in chores; globalization and the spread of Western democratic ideals; the appreciation of childhood and, consequently, of parental roles; the achievement of rights through the defense of LGBT causes, including in some countries, the legal recognition of the right to homoparenting; and the use of assisted reproduction techniques to enable parental desire (Barham \& Vanalli, 2012; Borsa \& Nunes, 2011; Esteca, 2012; Guimarães \& Petean, 2012).

As a result, there is an increase in the scientific literature of investigations addressing this context of changes in the family institution. However, even if advances are made, it still remains the contradictions between a discourse on behalf of the contemporary family ideal and empirically certified changes in incipient ways.

The term parenting emerged in the 1960s and designates the process of parental construction, in which maternal and paternal functions are not given a priori, as they are built through parental practices that update the psychic and affective links between parents and children. The very use of the term implies the ideology of fatherhood and motherhood exercised in more flexible ways, not implying homogenization of caregiving, but the possibility of performing parental functions that take into account, above all, the relationships of belonging and affection (Silva \& Solis-Ponton, 2004).

In the meantime, in the family of the heterosexual couples, gender-related parental roles are resignified by virtue of the immediate demands of caregiving. Thus, women's identity is dissociated from the maternal role as something naturalized, and her entry into the labor market opens up access to other social roles as important (or more) than motherhood. Continually, men enter the domestic sphere and the caring of children, which remains a typical female / mother's role, to build new parameters in paternal care and masculinity (Borsa \& Nunes, 2011).

In families consisting of homosexual couples, some studies indicate greater level of flexibility in parental caregiving, and division of household chores between the members of the couple (Rodriguez \& Gomes, 2012; Smith $\&$ Perry-Jenkins, 2012). In addition to these contexts, the kinship in reconstituted families is expanded and the division of care becomes more complex when added with stepmothers, stepparents, and half-siblings. (Rodriguez \& Gomes, 2012).

In this study we aim to conceptualize the term egalitarian parental care, based on a review of national (Brazil) and international literature in the last five years, as representation of a new dynamics of functioning of the parent / child relationship in contemporary times, prioritizing the focus of Psychology.

Currently other names have been created, such as coparenting or equally shared parenting. However, the first term also refers to the sharing of parenting between two couples (gay and lesbian) in parental exercise, establishing a restriction in the meaning that could make its use confusing. The second term, in turn, does not encompass the full complexity of the phenomenon we are approaching, as it refers to gender stereotypes arousing from discourse, leaving aside parental care as an egalitarian practice (Corrêa, 2012; Tiitinen \& Ruusuvuori, 2015).

The decision for the term egalitarian parental care, therefore, reflects a proposal that refers both to new references in parenting practices in diverse family contexts, as well as to the social, political and historical ideal that underlies this context of change, namely, the democratic ideal. Under the premise of winning, consolidating and maintaining rights extended to all, without discriminatory distinctions, there is a search for not only discursive equality, but also as a relational aegis that promotes repositioning and / or the creation of new positions with regard to parental care. 


\section{METHOD}

Considering that the topic analyzed is fragmented in the scientific literature, that is, the problems of new motherhood were dissociated from the fatherhood and vice versa, it is believed that knowledge produced around the new parental references demands a cohesive articulation, approaching the many angles of discussion, synthesizing them, and reflecting on correlated processes. Therefore, this review is justified to present a general framework, and to analyze the topic in a more integrated and deeper way.

Initially, we performed a general survey in scientific literature. No restrictions were made to the study areas of the articles, in order to verify the incidence and prevalence of investigations on the topic in recent years. The material collected refers to articles, theses and dissertations published from 2011 to 2015. Initially, the procedures for selection and storage of data were performed separately by two judges $\left(1^{\text {st }}\right.$ and $2^{\text {nd }}$ authors). Subsequently the data were compared, sorted and analyzed together. At all stages a third judge ( $3^{\text {rd }}$ author) evaluated and decided about the relevance and consistency of the material.

Electronic indexing databases used: SciELO, PePSIC, LILACS, Portal de Periódicos CAPES, Scopus and Biblioteca Virtual de Saúde - BVS. Descriptors: família/ family, paternidade/paternity/fatherhood, maternidade/ maternity/motherhood, casais de dupla carreira/dual career couples, família igualitária/egalitarian family. It is worth mentioning that the resource of pairing descriptors was used in the search for articles in big indexing databases, such as the Portal de Periódicos Capes and Scopus. This improved the selection procedures.

The number and diversity of descriptors is justified because the topic has been partially approached, since no articles directly referring to the objective proposed by this review could be found. Inclusion criteria: articles, dissertations or theses published in indexed journals; publications from January 2011 to December 2015; abstracts written in Portuguese, English, Spanish or French; articles related to the topic of contemporary parenting. No restrictions were made regarding the areas of study, methodological design or theoretical approach of the publications. Exclusion criteria: books, book chapters, reviews, minutes, letters, news, articles published before 2011 , articles not related to the theme of contemporary parenting.

\section{Procedures}

Stage 1 - identification. General selection of articles related to the topic, based on the abstracts. We found 64 national and 193 international articles. These were cataloged in tables (national and international) with the following specifications: article title, virtual access link, descriptor used, database consulted, year of publication, resumo/abstract/resumen/résumé, palavraschave/keywords/palabras clave/mots-clés, area of study, theoretical approach, type of method, correlated subject, journal of publication and place of reference of the study (for theoretical or review articles, the reference place of the professional affiliation institutions of the authors was highlighted; for empirical, statistical articles or desk research, the reference place of the research subjects was highlighted).

Stage 2 - 1st screening. Selection of articles about the topic under the Psychology light (47 national articles and 73 international articles), field of study of the authors.

Stage 3 - 2nd screening. Selection of 3 national and 28 international articles with terms directly related to egalitarian parental care, such as: relações igualitárias, atitudes igualitárias, divisão igualitária do trabalho, divisão de tarefas igualitária, igualdade, família igualitária, coparenting, ideal of gender equality, equally shared parenting, egalitarian actions, egalitarian relation, gender egalitarian division of labour, egalitarian housework arrangements, egalitarian housework patterns, egalitarian gender role concepts, egalitarian family environments, egalitarian ideal family life.

Stage 4 - Eligibility. From the 31 articles selected, we proceeded to the eligibility-related evaluation stage after reading the full texts. Eleven articles were excluded for not addressing the topic directly, 04 articles were not obtained due to lack of access to the full text, and 16 articles were included to serve as the basis for definition and deepening of the conceptual construction. The development of the stages described is illustrated in Figure 1.

The corpus of the study analysis was built in relation to the 16 articles included. This will be explained through the systematic presentation of the data collected. The material discussion will include a critical analysis about the 


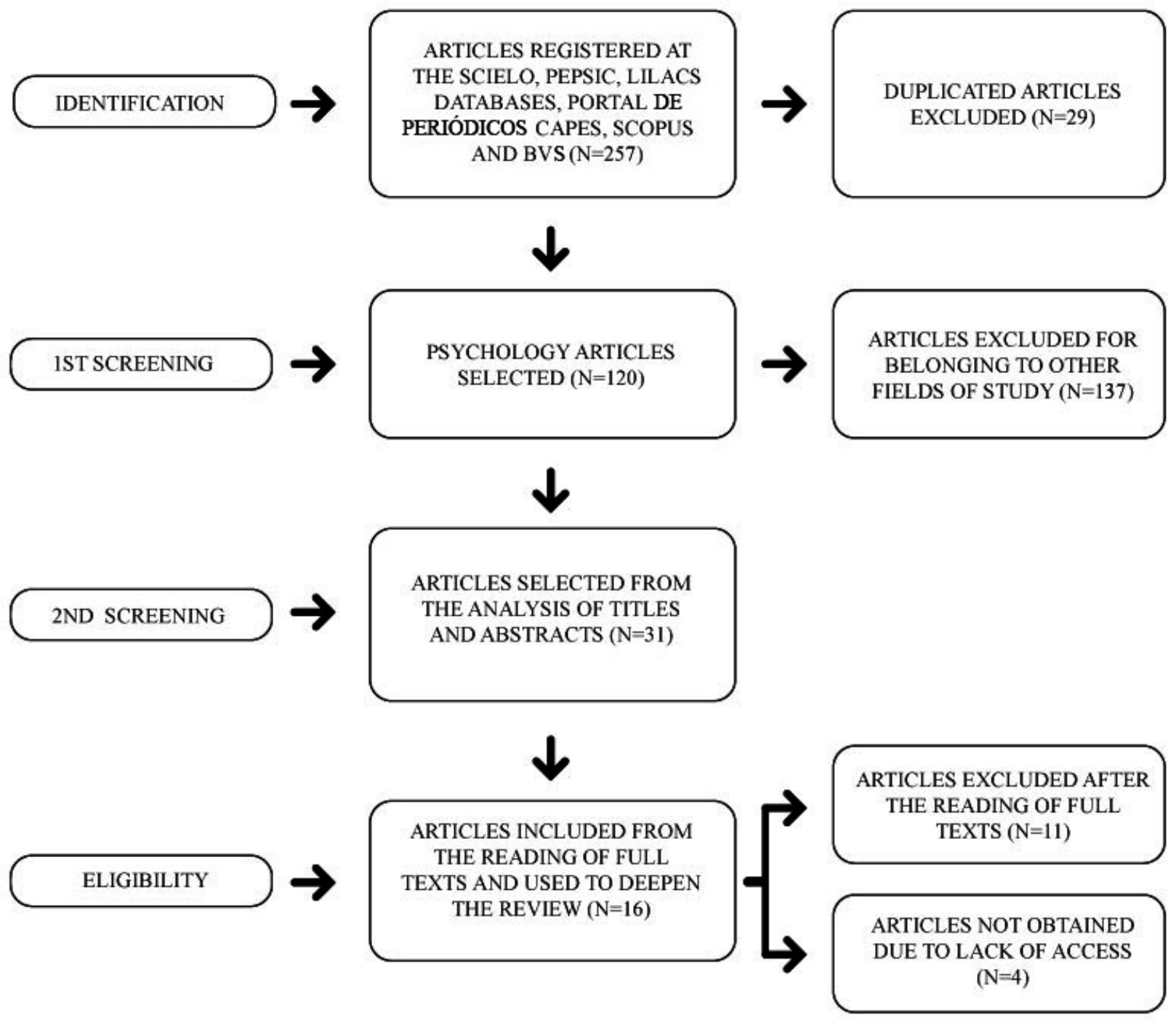

Figure 1. Flowchart with the procedures to select the articles analyzed.

conceptualization of the term egalitarian parental care, as well as the implications of the psychosocial phenomenon to which it refers to the various contexts described, through the following categories: assumptions for an egalitarian ideal of family; contemporary parenting; parenting versus work versus professional career; and egalitarian parenting.

\section{RESULTS}

\section{Regarding the Incidence of Investigations by Area of Study in the Period}

Several fields of study have investigated and brainstormed on the topic, with national and international production - Administration / Business (3.2\%; $\mathrm{n}=9$ ), Anthropology $(1.7 \% ; \mathrm{n}=5)$, Education $(1 \% ; \mathrm{n}=3)$, Nursing $(7.1 \% ; \mathrm{n}$ $=20)$, Medicine $(0.7 \% ; \mathrm{n}=2)$, Politics $(4.6 \% ; \mathrm{n}=13)$, Psychology $(42.7 \% ; \mathrm{n}=120)$, Public Health $(1.7 \%$; $\mathrm{n}$ $=5)$, Social Work $(1.4 \% ; n=4)$ and Sociology $(21.7 \%$; $\mathrm{n}=61)$; an area with only a national production - History
$(0.3 \% ; \mathrm{n}=1)$; and areas with only international production - Social Communication $(1.4 \% ; \mathrm{n}=4)$, Law $(1.4 \% ; \mathrm{n}=$ 4), Demographics $(2.4 \% ; n=7)$, Economics $(5.3 \% ; n=$ 15), Statistics $(0.3 \% ; n=1)$, Philosophy $(1.4 \% ; n=4)$ and Neuroscience $(1 \% ; \mathrm{n}=3)$.

It was observed that the prevalence of publications is concentrated on the field of Psychology, that every year presented an increasing quantity of articles, national (73.4\%; $\mathrm{n}=47)$ and international $(37.8 \% ; \mathrm{n}=73)$, compared to each of the other areas of study, with the exception of 2011 and 2014, where the international production of sociology 
was prevalent. In the national and international literature, they obtained the second highest incidence of publications, respectively, Nursing with $10.9 \%(\mathrm{n}=7)$ and Sociology with $32.6 \%(n=63)$ of the total of publications.

From 2011 to 2014, the average number of publications in the field of Psychology was relatively evenly distributed. Following are the national and international figures per year, respectively: $2011-45.8 \%(\mathrm{n}=11)$ and $54.1 \%(\mathrm{n}=13)$; $2012-47.8 \%(\mathrm{n}=11)$ and $52.1 \%(\mathrm{n}=12) ; 2013-50 \%(\mathrm{n}$ $=8)$ and $50 \%(\mathrm{n}=8) ; 2014-46.1 \%(\mathrm{n}=12)$ and $53.8 \%(\mathrm{n}$ =14). However, in 2015 the international publications of Psychology corresponded to $84.3 \%(n=27)$, while national publications to $15.6 \%(\mathrm{n}=5)$. That was also the year with more publications on the topic of contemporary parenting, an increase observed even in other fields of study, which may be correlated to elements of legitimation, diffusion and consolidation of the phenomenon itself.

Regarding the average of publications in other areas over the 5 years, we found significant prevalence of international publications, both quantitatively and qualitatively. The proportionality ratio of the total number of publications in each year presented an average in which the international production was approximately 7 times higher than the national one. Following are comparative results between the totals of all fields of study, respectively, national and international: $2011-12.9 \%(\mathrm{n}=4)$ and $87 \%$ $(\mathrm{n}=27) ; 2012-17.2 \%(\mathrm{n}=5)$ and $82.7 \%(\mathrm{n}=24) ; 2013$ $-15 \%(\mathrm{n}=3)$ and $85 \%(\mathrm{n}=17) ; 2014-9.6 \%(\mathrm{n}=3)$ and $90.3 \%(\mathrm{n}=28) ; 2015-9.5 \%(\mathrm{n}=4)$ and $90.4 \%(\mathrm{n}=38)$.

\section{Regarding the Methodological Outline of Investigations}

Considering the 257 articles identified in the national and international literature, without a restriction of fields of study, the following methodological outlines were found: exclusively theoretical research methodology $(16.7 \% ; n=43)$, empirical research from field investigations $(69.6 \% ; n=179)$, literature reviews $(5 \% ; n=13)$, desk research $(2.3 \% ; n=6)$, and exclusively statistical analysis studies $(6.2 \% ; n=16)$.

Empirical designs include case studies, qualitative exploratory and descriptive studies, quantitative descriptive and statistical studies, intercultural and comparative, longitudinal studies, research with both quantitative and qualitative methodology, clinical studies, interventional, ethnographic, follow-up research and evaluation of intervention programs.

Considering the higher incidence of the empirical methodological approach in relation to other types of approaches, we inferred that egalitarian parental care was broached in studies that denote an attempt to present not only a new parental ideal in discursive terms, but also the reaching of this discourse on parental practices.

\section{Regarding Global and National Distribution of the Scientific Production}

Table 1 shows the worldwide geographic distribution of scientific production on this topic:

It is observed a diffusion of investigations, which contributes to the wide exploration of the phenomenon in different contexts (mainly at international level) and, in some cases, with extremely opposite realities regarding the structural transformations that the family goes through these days.

Table 2 shows the distribution of the scientific production on the topic by Regions/States of Brazil:

There is a high concentration of publications in the Southeast and South regions of Brazil, which could be a result of following factors: higher incidence of the phenomenon in these regions, still incipient interest in the theme in other Brazilian regions, greater number of Postgraduate Programs and the higher degree of education of the population. Confirmation of these inferences would support the need for further investigation in varied socioeconomic-demographic contexts.

After presenting the general results, with no restriction as to the fields of study and highlighting the production of Psychology around the topic, we started the analysis of the 16 articles selected from this area, as they are indexed with terms (in abstracts or keywords) that refer to egalitarian parenting. After being fully read, these articles were considered to be directly related to the objective of building the concept of egalitarian parental care.

\section{DISCUSSION}

\section{Assumptions for an Egualitarian Ideal in Families}

According to Araújo (2011) equality, as a value and a right, dates back to the French Revolution and the institution of modernity. However, the advent of the democratic state, grounded in a time when androcentric and misogynistic conceptions prevailed, limited these emerging rights exclusively to men. Other revolutions were necessary for women to win these rights such as: the industrial revolution, the institution of capitalism as an economic system, the spread of democracy as a political system, the feminist revolution, the sexual revolution with the creation of the birth control pill, the change in legislation regulating the right to divorce, the urbanization process, and the globalized culture (Trifan, Stattin, \& Tilton-Weaver, 2014).

In this scenario, feminism was indispensable to mitigate hegemonies and inequalities rooted in the dominant relations 
Table 1

Distribution of scientific production on the topic by Continents/Countries

\begin{tabular}{|c|c|c|}
\hline CONTINENTS & COUNTRIES & WORLD PRODUCTION * \\
\hline \multirow{7}{*}{$\begin{array}{l}\text { AMERICA } \\
50,1 \%(n=129)\end{array}$} & Brazil & $24.9 \%(n=64)$ \\
\hline & United States & $17.1 \%(n=44)$ \\
\hline & Chile & $2.3 \%(n=6)$ \\
\hline & Mexico & $2.3 \%(\mathrm{n}=6)$ \\
\hline & Canada & $1.9 \%(\mathrm{n}=5)$ \\
\hline & Colombia & $0.7 \%(\mathrm{n}=2)$ \\
\hline & Peru/Nicaragua & $0.6 \%(\mathrm{n}=2)^{\mathrm{a}}$ \\
\hline \multirow{15}{*}{$\begin{array}{l}\text { EUROPE } \\
31,5 \%(n=81)\end{array}$} & Germany & $5.4 \%(\mathrm{n}=14)$ \\
\hline & United Kingdom & $4.6 \%(n=12)$ \\
\hline & Portugal & $3.1 \%(\mathrm{n}=8)$ \\
\hline & Sweden & $3.1 \%(\mathrm{n}=8)$ \\
\hline & Finland & $1.9 \%(n=5)$ \\
\hline & Spain & $1.5 \%(n=4)$ \\
\hline & Switzerland & $1.5 \%(n=4)$ \\
\hline & France & $1.1 \%(n=3)$ \\
\hline & Austria & $1.1 \%(n=3)$ \\
\hline & Denmark & $1.1 \%(n=3)$ \\
\hline & Norway & $1.1 \%(\mathrm{n}=3)$ \\
\hline & Italy & $0.7 \%(\mathrm{n}=2)$ \\
\hline & Holand & $0.7 \%(n=2)$ \\
\hline & Stonia & $0.7 \%(\mathrm{n}=2)$ \\
\hline & $\begin{array}{c}\text { Slovakia / Slovenia / Croatia / Serbia / Cyprus / } \\
\text { Poland / Ireland }\end{array}$ & $2.1 \%(\mathrm{n}=7)^{\mathrm{a}}$ \\
\hline \multirow{5}{*}{$\begin{array}{l}\text { ASIA } \\
6 \%(n=16)\end{array}$} & Japan & $1.5 \%(n=4)$ \\
\hline & China & $0.7 \%(n=2)$ \\
\hline & India & $0.7 \%(\mathrm{n}=2)$ \\
\hline & South Korea & $0.7 \% ; \mathrm{n}=2)$ \\
\hline & $\begin{array}{c}\text { Philippines / Russia / Israel / Singapore / } \\
\text { Vietnam / Malaysia }\end{array}$ & $1.8 \%(\mathrm{n}=6)^{\mathrm{a}}$ \\
\hline \multirow{2}{*}{$\begin{array}{l}\text { OCEANIA } \\
4 \%(n=10)\end{array}$} & Australia & $3.5 \%(n=9)$ \\
\hline & New Zeeland & $0.3 \%(\mathrm{n}=1)^{\mathrm{a}}$ \\
\hline $\begin{array}{l}\text { AFRICA } \\
0,3 \%(n=1)\end{array}$ & South Africa & $0.3 \%(\mathrm{n}=1)^{\mathrm{a}}$ \\
\hline
\end{tabular}

Source: SCIELO, PEPSIC, LILACS, Portal de Periódicos CAPES, SCOPUS and BVS.

Note: It is noteworthy that $7.7 \%(\mathrm{n}=20) *$ of the total of publications correspond to multinational studies in which intercultural and comparative investigations were conducted between at least two countries.

Note ${ }^{a}$ : Sum of percentages and Ns of countries that presented the production of only one article.

of men over women (Araújo, 2011; Viala, 2011). From equality valued by the modern democratic state to the egalitarian relations advocated in contemporary times, there is the gap of transformations that culminated in a process of family democratization, which has increasingly ruled the relations between men, women and children (Araújo, 2011). In the interplay of these relationships, the authoritarian and remnant paradigm of patriarchal ideology gives way to the affective paradigm, linked on the one hand to the valorization of childhood and parenting functions and, on the other hand, intrinsically linked to the multiplicity of gender representations and the deconstruction of male and female stereotypes.

Another parameter of change aimed at an egalitarian ideal took place through the subversion of the access between the public and the private. The current reality of relations between family members shows an increasingly access of women to the labor market, to better levels of professional qualification and to their performance in several social and political spheres. In addition, some men are showing a growing interest in being part of the home environment. Financial support becomes the couple's 
Distribution of scientific production on the topic by Brazilian Regions/States

\begin{tabular}{|c|c|c|}
\hline REGIONS & STATES & BRAZILIAN PRODUCTION * \\
\hline \multirow{3}{*}{$\begin{array}{l}\text { SOUTHEAST } \\
43,1 \%(n=28)\end{array}$} & São Paulo & $26.1 \%(\mathrm{n}=17)$ \\
\hline & Rio de Janeiro & $12.3 \%(\mathrm{n}=8)$ \\
\hline & Minas Gerais & $4.6 \%(n=3)$ \\
\hline \multirow{3}{*}{$\begin{array}{l}\text { SOUTH } \\
37,1 \%(n=24)\end{array}$} & Rio Grande do Sul & $27.6 \%(n=18)$ \\
\hline & Santa Catarina & $7.6 \%(\mathrm{n}=5)$ \\
\hline & Paraná & $1.5 \%(\mathrm{n}=1)$ \\
\hline \multirow{5}{*}{$\begin{array}{l}\text { NORTHEAST } \\
9,2 \%(n=6)\end{array}$} & Ceará & $3 \%(n=2)$ \\
\hline & Alagoas & $1.5 \%(\mathrm{n}=1)$ \\
\hline & Pernambuco & $1.5 \%(\mathrm{n}=1)$ \\
\hline & Paraíba & $1.5 \%(\mathrm{n}=1)$ \\
\hline & Bahia & $1.5 \%(\mathrm{n}=1)$ \\
\hline \multirow{2}{*}{$\begin{array}{l}\text { MID-WEST } \\
3 \%(n=2)\end{array}$} & Mato Grosso & $1.5 \%(n=1)$ \\
\hline & Distrito Federal & $1.5 \%(n=1)$ \\
\hline \multirow{2}{*}{$\begin{array}{l}\text { NORTH } \\
3 \%(n=2)\end{array}$} & Amazonas & $1.5 \%(\mathrm{n}=1)$ \\
\hline & Pará & $1.5 \%(\mathrm{n}=1)$ \\
\hline
\end{tabular}

Source: SCIELO, PEPSIC, LILACS, Portal de Periódicos CAPES, SCOPUS and BVS.

Note: It is noteworthy that $4.6 \%(\mathrm{n}=3)$ * of the total number of publications correspond to multiregional studies in which intercultural and comparative investigations were conducted between at least two states.

responsibility, and domestic tasks are distributed following criteria that go beyond pre-established definitions of roles and functions typically oriented by gender (Bilac, 2014).

Democratization, however, continues to set aside several social and cultural contexts, as it is not equally extended to the many population segments, focusing on intellectualized and of greater socioeconomic power segments. This relative, and therefore unequal, equality is challenged as a relational model and is evidenced in many cases only as an emerging discourse still far from the apprehended reality. According to Rodriguez and Gomes (2012), considering the succession of rights that were won and recognized, it is now necessary to think over a process of construction of new references, acting on the reformulation of values, discourses and practices in the family.

\section{Contemporary parenting}

Since the feminist struggles, motherhood, sometimes associated with a submission to men (radical feminist movement), sometimes advocated for as a female social role subject to remuneration (maternal movement), underwent significant transformations (Gradvohl et al., 2014). Under the scrutiny of incisive contestations, maternal love has been attested as a myth and the conception of a feminine nature focused exclusively on the caring of the domestic environment and the children has been denaturalized, and understood as a normative and cultural construction in the designation of women's identity (Badinter, 1980).
The idea embedded in the social imaginary and that echoes in several social areas is that caregiving is always of the female order. The "nature" that predisposes women to go through pregnancy presumes maternal and primary care as self-evident, unlike paternal care (Tiitinen \& Ruusuvuori, 2015). This biological imperative has also been observed in studies of lesbian couples which, in some cases, biological mothers spent more time with their child compared to their nonbiological mother (Malmquist, 2015).

Other ideas present in this context are the contradictory social expectations related to the link between motherhood and women's identity completeness, and between motherhood and renunciation. Thus, in the light of the changes around female and maternal identity, several studies indicate, under the traditional gender imperatives and the centrality of the maternal profile, the suffering of women who have experienced parenting in a conflicting way in view of the quantitative and qualitative responsibilities in the caregiving and education of children (Fiorin, Oliveira, \& Dias, 2014; Guimarães \& Petean, 2012).

The idyllic maternal completeness is increasingly demystified and, to avoid renunciations resulting from the maternal role, some women have opted for not having children and to invest in their professional career, while others decided for postponing maternity. It is observed that the phenomenon of late pregnancy is growing and generating numerous controversies. According to Fiorin et al. (2014), in a study conducted with women who postponed the maternity project, found that this choice is related to 
the following aspects: negative - adverse pregnancy; poor physical disposition; in addition to medical, psychological and other health professional interventions; positive - better economic, social and emotional conditions; and greater maturity to reconcile domestic and work activities.

We could also mention some studies that discuss the contexts involved in biological, surrogate, and social maternity (Gradvohl et al., 2014). Although the statute of sacrificial motherhood for the good of the family operates in social discourses, the deconstruction of what is maternal in the midst of questioning of both gender roles and the emphasis on biological as primordial attachment brings new possibilities and conditions for women to exercise parenting.

The other side of this reality concerns the reconfigurations of masculine and paternal roles. If in the past studies on motherhood was prevailed, today there is a growing interest in the father's engagement in the care of the baby and child. Among the benefits and repercussions of paternal affective involvement for the child's development, the following indicators were found: the father playing the encouraging role for breastfeeding; contact with the father after childbirth serving as a factor of well-being; the father as a facilitator of environmental exploration and as a promoter of positive self-image; greater trust of the child in the father as a caregiver figure; enrichment of social and motor development; encouragement of obedience and competitive engagement; the father as an example of the transmission of new male roles; paternal presence in the prevention of antisocial behaviors; promotion of self-esteem, security, independence and emotional stability; better academic performance of children associated with a greater parental participation in school activities; aggressiveness control; paternal engagement associated with better psychosocial adjustment in adolescence and adulthood (Benczik, 2011; Castoldi, Gonçalves, \& Lopes, 2014; Röhr-Sendlmeier \& Bergold, 2012; Zvara, Schoppe-Sullivan, \& Dush, 2013).

Paternal engagement has also been associated with preventive and supportive functions in cases of maternal depression and unresponsiveness, as well as negative complications during pregnancy, such as studies investigating the importance of skin-to-skin contact (Method Kangaroo) between father and preterm baby (Piccinini, Silva, Gonçalves, Lopes, \& Tudge, 2012).

Although women still appear as the main caregivers, the caregiver role played by men challenges old stereotypes of a parenthood distantly referenced as exclusively responsible for financial support and authority. Men are appropriating the domestic environment to resignify their participation and take on new places as fathers. The sharpest changes observed are after the baby's first year. According to Zvara et al. (2013), this would be justified by the fact that during this period the child still establishes an intense relationship of dependence with the mother, which would lead the father to a secondary role in caregiving.
In contrast to this maternal emphasis during early development, emerges the representation of the pregnant couple and of the man that is actively engaged in the pregnancy-puerperal process. In this new paternal positioning a phenomenon, called Couvade syndrome, is investigated. It designates the manifestation of psychological and organic changes in men throughout the pregnancy of women. The syndrome has been understood as a kind of identification or appropriation of the pregnant woman's place causing the man to "gestate" symptomatically. According to Lamour (2008), it is possible for men to be emotionally involved in the process of pregnancy without taking over their maternal role and safeguarding their masculinity.

Factors such as socioeconomic status, sex of the baby, social support network and education level have been described as sometimes correlated with higher, sometimes non-determinant, paternal engagement (Seabra \& Seidl-deMoura, 2011; Zvara et al., 2013). In addition to this scenario of inferences and findings, the massive scientific production that certifies the permanence of women as primary caregivers and selective parental participation, in most cases associated with playful interactions and child discipline (Arruda \& Lima, 2013; Castoldi et al., 2014; Piccinini et al., 2012).

Despite the incentive and discourse for a new fatherhood, the role of caregiver played by men is still impaired by the traditional gender prejudices found in various institutions focused on family care. These prejudices can also come from extended families, women, and men themselves, who feel uncomfortable to perform activities defined as "female labor" (Tiitinen \& Ruusuvuori, 2015; Zvara et al., 2013).

The nuances that make up the context of family transformations identified in this study, especially in discussions about parenting based on heterosexual couples, support the progress in research on relationships established between the father-mother-baby / child triad. Studies exclusively focused on the mother-infant / child dyad and that perpetuated the emphasis on the caregiver position of the mother are being overtaken by those that include the father's contributions to the intersubjective dynamics.

\section{Parenting x Work x Career: Conciliations and Conflicts}

The effective participation of women in society as an element of economic and political mobilization began in Western Europe and North America, and then expanded worldwide. In Brazil this expansion occurred from the Southeast to the other regions. In general, there is a process of consolidation and diffusion of female paid work that started in the regions that are most developed, urbanized and with the best socioeconomic and educational possibilities (Barham \& Vanalli, 2012). 
In the current professional setting, women fall into a wide range of specialties, including those previously considered predominantly male. If women also become the home provider, some studies present statistical data that illustrate a significant increase in the number of so-called matrifocal families, with female leadership and the predominance of women in family support, maybe resulting from broken marital unions (divorce), interrupted unions (death of a partner), or by single mothers (Fiorin et al., 2014). However, it is observed that these female leaders are correlated to studies that refer to family contexts in which there is an absence of the father figure, and no studies were found in which female leadership was in heterosexual couples.

Men also get inserted in the family environment to assist in works as childcare and home supporting activities. Viala (2011), Rehel (2014) and Smith and Perry-Jenkins (2012) emphasize, however, that male participation proved to be more effective in children care than in household chores, where men remain in a more collaborative or peripheral role. Kosakowska-Berezecka et al. (2016) understand this distinction as resulting from the fact that childcare would be associated with the notion of paternity and not detached from masculinity, while housework would be seen as devalued and a threat to male identity.

Moreno (2011) argues that citizenship, as a democratic right, would be articulated to the public space, where male way of living is the reference. In the reconciling of family and professional responsibilities, private and domestic spaces would therefore be neglected as a democratic and citizenship issue, perpetuating the sexist division of labor in this area.

In the reconciliation between family and professional life, it emerges the categories double-earning couples (both partners contribute financially to the family provision) and double-career couples (besides contributing to the financial provision, invest in training and professional qualification through training courses, lato sensu and stricto sensu postgraduate courses) (Quek, Knudson-Martin, Orpen, \& Victor, 2011; Ruitenberg \& Beer, 2014). Even in doubleearning or double-career couples, women still spend more time on housework and childcare than men, what in most cases establishes a functioning dynamic that causes an overload of attributions for the woman. There is also the triple shift of women, i.e., the division of efforts and time between work, professional qualification and family life (Guimarães \& Petean, 2012; Quek et al., 2011).

Thus, if on one hand women's work is associated with greater personal satisfaction, increased self-esteem, autonomy, sense of usefulness and competence, better physical and mental health and positive repercussions on the quality of the marital relationship; on the other hand, difficulties arise in dealing with an androcentric workplace discourse on motherhood (priority for female candidates who have greater availability of mobility and time), associations between female work and neglect of their children, which also come from women themselves, and the eruption of marital crises in the administration of multiple simultaneous functions (Fiorin et al., 2014).

The perception of excessive female work (paid and domestic) is also relative, because in some cases women report not feeling overwhelmed, in others the unequal division of tasks has generated feelings of injustice, depressive symptoms and marital dissatisfaction. To avoid the difficulty of reconciling family and domestic activities for men and women, outsourced services such as nannies, nurseries and daycare centers are used. In addition, in some places the government, along with family-friendly or fatherfriendly companies, (Kosakowska-Berezecka et al., 2016; Ruitenberg \& Beer, 2014; Stevens, 2015) have set policies and strategies to relieve stress and promote reconciliation between work and family, such as daycare centers, flexible working hours and an increased paternity leave, a fact that has already been associated with better collective productive performance by these companies.

Another element with high potential for transformation in the context of family relationships, especially regarding the period of initial parental care of the child, refers to the legislation on maternity leave and paternity leave. In some countries, a kind of parental leave is already in place, which takes into account the continued absence of work by the couple (alternately or jointly) for the first year of the child's life. Following are some specifications of leave with parameters of almost total disregard for the importance of paternal role in early child development to the consideration of the importance of parental couple, including granting rights also to homosexual couples: (United States) maternity leave 12 weeks unpaid, no paternity leave legislation (Rehel, 2014); (Brazil1) paid maternity leave from 16 weeks to 24 weeks and paternity leave from 5 to 20 days (Fiorin et al., 2014); (Singapore) 16-week maternity leave and 6-day paternity leave (Quek et al., 2011); (Australia) 18 weeks paid parental leave, 2 weeks non-transferable to father (Trifan et al., 2014); (Canada) paid maternity leave of 15 weeks for the mother and 35 weeks of parental leave divided between the couple (Rehel, 2014); (Sweden) 32-week paid parental leave, 30 non-transferable days for each member of the couple, and 180 days transferable to both mother and father (Malmquist, 2015); (Germany) 48-week paid maternity leave, 48-week paid paternity leave, in this country there is also the possibility to take the child up to 3 years of age, but after the first year there would be no remuneration. Furthermore, maternal and paternal conditions can be enjoyed at any time during the child's first 3 years (Schulz \& Rost, 2012).

1 Employees from organizations that participate in the Program Citizen Firm, sanctioned by the Dilma Rousseff government, have the right to a maternity leave of 180 days, and a paternity leave of 20 days (Decreto Lei $\mathrm{n}^{\mathrm{o}} 11.770$ de 9 de setembro da Subchefia para assuntos jurídicos, 2008) 
This review clearly shows that while in Brazil discussions focus on the challenges faced by women when they started joining the labor market and the conflicts and reconciliations between family and labor demands; in the international literature, in addition to these problems, articles were also found that reflect on the conditions and implications of parental leave in different countries. This difference may derive from the greater framing of the phenomenon of egalitarian parental care at international level, while in Brazil the discrepancy between maternal and paternal leave still delays the process of changes in the equitable division of parental roles and functions.

\section{Egalitarian Parental Care}

In the scope of what we call here egalitarian parental care, a new ideal is inserted for women and men, in view of the contemporary demands of reconciling personal desires and social demands, especially regarding parental exercise. Contemporary women's identity encompasses multiple roles as a successful professional, financial provider, mother, and wife; while men's identity is no longer completed only with their professional career, assimilating the roles of child caregiver and partner in daily domestic activities, even if a slow pace (Fiorin et al., 2014).

Because of the clear disadvantages suffered by women due to multiple unequally administered attributions, they are pointed out as the member of the relationship that most defends an egalitarian family model (Trifan et al., 2012). And although there is an openness to this family model, men only defend it to the extent that it does not pose a threat to their masculinity, a fact indicated by Kosakowska-Berezecka et al. (2016) in a study in which men who felt confident in their masculinity tended to endorse more egalitarian opinions.

Currently, parenting is presented as a project of the couple, subject to control, planning and negotiation according to short- and long-term conveniences and limitations (Viala, 2011). This venture has challenges to be overcome and spaces to be won. If there is a tendency towards the valuation of qualification and professional outcomes, regardless of gender, egalitarian relations are pointed as a factor that could bring quality of life, reduce conflicts between work and family, and denaturalize the association between motherhood and renunciation (Kosakowska-Berezecka). et al., 2016).

A new paternity implies a new maternity. This correlation is concerned with the ambivalent attitudes of mothers regarding paternal insertion in childcare. Zvara et al. (2013) approach this issue referring to a phenomenon in which mothers act as gatekeepers, facilitating gate-opening or resisting to give away the primacy of caregiving (gateclosing). Another phenomenon also reported in the scientific literature is that of stay-at-home fathers, that designates the paternal decision to relinquish paid work, temporarily or permanently, to stay at home with their children and taking care of domestic activities, while women are responsible for the family provision (Rehel, 2014; Stevens, 2015).

Egalitarian parental care has also been depicted in some studies that discuss homoparenting, described based on parameters such as the absence of fixed roles between the couple's members, the absence of hierarchies, the circulation of leaders, distinct authority references, female and male places not coincident with those occupied by men and women, maternal and paternal duties performed by either partner (even though one of the roles is most prominently performed by one of the parental figures). Other studies also argue that gay and lesbian couples would be less vulnerable to heteronormative constructions that focus on issues such as: division of responsibilities based on paid or unpaid work, wage differences and educational attainment (Malmquist, 2015; Rodriguez \& Gomes, 2012; Smith \& Perry-Jenkins, 2012).

Rodriguez and Gomes (2012), referring to homoparenting, developed the thesis that this parental and family configuration establishes in its building an incessant challenging of the model of complementarity between male and female. According to the authors, what is proposed from the homoparental family is the formulation of a constitutive logic of the human being in which there is a supremacy of links and functions, regardless of the biological sex of those who exercise them.

Some countries as Sweden, the Netherlands and Canada promote significant advances towards a more egalitarian society; others such as Poland and the United States would still be at a predominantly discursive level of assimilation (Kosakowska-Berezecka et al., 2016; Rehel, 2014; Ruitenberg \& Beer, 2014; Smith \& Perry-Jenkins, 2012). In Brazil, egalitarian discourse is already emerging in the horizon of thinking over contemporary parenting; however, non-traditional gender roles are assimilated at slow pace (Rodriguez \& Gomes, 2012).

In some studies it was found that the term coparenting, associated with a shift from peripheral parenting to affectively implicated parenting in childcare, could also be correlated with egalitarian parental care (Viala, 2011; Zvara et al., 2013). According to Quek (2011), coparenting would be facilitated when: a woman's career is valued by the couple, the man structures his agenda to actively engage in parenting, parental responsibility is shared and negotiated, and access to support from extended family and work environment is guaranteed.

Therefore, egalitarian parental care, understood based on the present bibliographical survey undertaken, is situated in the sharing of democratic ideals among family members, resulting in egalitarian division of care and work (paid and unpaid) between the couple; taking into account the immediate and individual needs, and reconciling them with the well-being of the family group. In this model of parental care rights would be guaranteed in view of the suppression of hierarchies of powers, and in the assumption of horizontal and flexible relations with respect to the negotiation of parenting practices. 


\section{FINAL REMARKS}

Considering what has been presented herein, we consider that the phenomenon we call egalitarian parental care is being consolidated in several countries. Among the many areas of knowledge involved with the subject, Psychology has been highlighted as the main area interested in the subject, given the amount of articles published compared to other disciplines, both nationally and internationally, followed by Sociology.

If we associate the factor above with the higher incidence of empirical research, we can hypothesize that there is an increase in attempts to understand these new ways of being a family, based on the real experience of individuals, and on a pressing need, typical of the human sciences, to build scientific knowledge that gives psychological and social legitimation to these new relational dynamics.

Among the main contributions that could result from advances in egalitarian parental care, we could mention the possibility of rethinking public policies that focus only on the mother-baby dyad, with little consideration for the father in this process. In Brazil, the valorization of maternity over paternity is revealed when comparing maternal and paternal leave, since while paid maternity leave varies from 16 weeks to 24 weeks, paternity leave varies from 5 to 20 days. Thus, Brazilian studies are still in the process of consolidating the phenomenon, especially compared to some international studies; however, they are of fundamental importance to think about specific policies for the Brazilian population. If we rule the implementation of egalitarian parental care based on the existence of parental leave and no longer maternity as legal data, we can say that in countries such as Sweden, the Netherlands, Canada and Denmark this experience is already implemented, comparatively other countries that remain stuck to tradition, such as Spain and Brazil.

This study is a contribution to the conceptualization of an ongoing phenomenon. However, although we recognize that this may be a new trend that interferes with conjugality and parenting, we emphasize that understanding this type of family experience demands more diversified and deeper investigations about its incidence in the various social segments. Factors such as race, socioeconomic status, education level, social support network, gender and age of children, number of children, among others, influence the access to equality of political and social rights in the private sphere. In the full guarantee of these rights, is egalitarian parental care effective?
The conjuncture of the phenomenon is complex and encompasses contradictory components precisely because it focuses on gender stereotypes rooted in various societies, such as the myth of maternal love and the masculinity affirmed in opposition to what is considered feminine. However, in addition to prejudices and justifications that take into account only deterministic and restrictive aspects, we also come across political, social and legal issues that perpetuate the traditional model in which women belong to the private space, while men the public.

In the practice of egalitarian parental care the beliefs, values and references of family models assimilated by the individuals themselves also act in a conflictive way, a fact observed in cases of women that do not give up being the main reference of caregiving for their children and consider that men's participation in household chores is a female concession. Or, when men restrict themselves to the role of provider and the other functions are neglected or overcharged. We consider that these conflicts are the result of the coexistence of the traditional model with the new trend that breaks with stereotypes of the man / father and the woman / mother.

We emphasize that what we propose to be egalitarian parental care neither denies gender differences nor denies the biological aspects to build parenting. The differences are intrinsic and the right to choose and to be able to exercise parental care without traditional gender imperatives can contribute to a more democratic parenting.

As it is a new concept and still under construction, this study has methodological limitations. To perform the literature review, we need to use several descriptors. In addition, not all articles selected by the abstracts were related to the topic, resulting in relatively small sample of studies that addressed the phenomenon of egalitarian parental care. Most studies is still approaching the topic and deals with it in an exploratory manner.

No articles were found that proposed a definition for egalitarian parental care, but some studies in Brazil, Switzerland and the United States are paying attention to triadic relations, valuing this new way of parenting and moving away from what is already well known about the relationship mother / baby / child. This fact justifies the relevance of the present review and the importance of developing new studies that try to understand how caregiving is effectively provided to children in an egalitarian manner, and the impacts of this phenomenon on conjugality and child development. 


\section{REFERENCES}

Araújo, M. F. (2011). Família, modernização capitalista e democracia: Retomando alguns marcos do antigo debate sobre as transformações da família no Brasil. Tempo e Argumento, 3(1), 180-198.

Arruda, S. L. S. \& Lima, M. C. F. (2013). O novo lugar do pai como cuidador da criança. Estudos Interdisciplinares em Psicologia, 4(2), 201-216

Badinter, E. (1980). L'indifférence maternelle. In E. Badinter, L'amour em plus - Histoire de l'amour maternel - XVII ${ }^{\circ}-X X^{\circ}$ siècle (pp.73-136). Flammarion, Paris.

Barham, E. J., \& Vanalli, A. C. G. (2012). Trabalho e família: Perspectivas teóricas e desafios atuais. Revista Psicologia: Organização e Trabalho, 12(1), 47-60.

Benczik, E. B. P. (2011). A importância da figura paterna para o desenvolvimento infantil. Revista Psicopedagogia, 28(85), 67-75.

Borsa, J. C., \& Nunes, M. L. T. (2011). Aspectos psicossociais da parentalidade: O papel de homens e mulheres na família nuclear. Psicologia Argumento, 29(64), 31-39.

Bilac, E. D. (2014). Trabalho e Família - Articulações possíveis. Tempo Social, 26(1), 129-141.

Castoldi, L., Gonçalves, T. R., \& Lopes, R. C. S. (2014). Envolvimento paterno da gestação ao primeiro ano de vida do bebê. Psicologia em Estudo, 19(2), 247-259).

Corrêa, M. E. C. (2012). Duas mães? Mulheres lésbicas e maternidade (Tese de doutorado). Faculdade de Saúde Pública, Universidade de São Paulo, São Paulo, SP, Brasil.

Decreto Lei ${ }^{\circ} 11.770$ de 9 de setembro da Subchefia para assuntos jurídicos. (2008).

Esteca, F. M. (2012). A mãe que trabalha fora: A criança e a familia em relação ao trabalho materno (Dissertação de Mestrado). Programa de Pós-graduação em Psicologia Clínica, Instituto de Psicologia, Universidade de São Paulo, São Paulo, SP, Brasil.

Fiorin, P. C., Oliveira, C. T., \& Dias, A. C. G. (2014). Percepções de mulheres sobre a relação entre trabalho e maternidade. Revista Brasileira de Orientação Profissional, 15(1), 25-35.

Gradvohl, S. O., Osis, M. J. D., \& Makuch, M. Y. (2014). Maternidade e forma de maternagem desde à Idade Média à atualidade. Pensando Famílias, 18(1), 55-62.

Grossi, M. P. (2003). Gênero e parentesco: Famílias gays e lésbicas no Brasil. Cadernos Pagu, 21, 261-280.

Guimarães, M. G. V., \& Petean, E. B. L. (2012). Carreira e família: Divisão de tarefas domiciliares na vida de professoras universitárias. Revista Brasileira de Orientação Profissional, 13(1), 103-110.

Kosakowska-Berezecka, N., Besta, T., Adamska, K., Jaskiewicz, M., Jurek, P., \& Vandello, J. A. (2016). If my masculinity is threatened I won't support gender equality? The role of agentic self-stereotyping in restoration of manhood and perception of gender relations. Psychology of Men \& Masculinity, 17(3), 274-284.

Lamour, M. (2008). Construir conjuntamente a paternidade: uma experiência de pesquisa, ação e formação na creche. In J. André
\& C. Chabert (Eds.), O esquecimento do pai (pp.79-109). São Paulo, Editora da Universidade de São Paulo - EDUSP.

Malmquist, A. (2015). Women in lesbian relations: Construing equal or unequal parental roles? Psychology of Womem Quarterly, $39(2), 256-267$

Moreno, J. M. G. (2011). A conciliação entre a vida familiar e a vida profissional no Direito Comunitário: Uma análise jurídicofeminista. Ex Aequo, 23, 39-52.

Piccinini, C. A., Silva, M. R., Gonçalves, T. R., Lopes, R. C. S., \& Tudge, J. (2012). Envolvimento paterno aos três meses de vida do bebê. Psicologia: Teoria e Pesquisa, 28(3), 303-314.

Quek, K. M. T., Knudson-Martin, C., Orpen, S., \& Victor, J. (2011). Gender equality during the transition to parenthood: A longitudinal study of dual-career couples in Singapore. Journal of Social and Personal Relationships, 28(7), 943-962.

Rehel, E. M. (2014). When dad stays home too: paternity leave, gender, and parenting. Gender \& Society, 28(1), 110-132.

Rodriguez, B. C., \& Gomes, I. C. (2012). Novas formas de parentalidade: Do modelo tradicional à homoparentalidade. Boletim de Psicologia, 63(136), 29-36.

Röhr-Sendlmeier, U. M., \& Bergold, S. (2012). Father's role when mother is working - family involvement, life satisfaction and children's scholastic achievement. Journal of Family Research, 24(1), 3-26.

Ruitenberg, J., \& Beer, P. (2014). Exploring the social origins of Dutch mothers' ideal family lives. Sex Roles, 70, 315-328.

Schulz, F., \& Rost, H. (2012). Division of housework, maternity leave and the policy of parenting benefit in Germany. Journal of Family Research, 24(1), 27-45.

Seabra, K. C., \& Seidl-de-Moura, M. L. (2011). Cuidados paternos nos primeiros três anos de vida de seus filhos: Um estudo longitudinal. Interação em Psicologia, 15(2), 135-147.

Silva, M. C. P., \& Solis-Ponton, L. (2004). Ser pai, Ser mãe Parentalidade: um desafio para o terceiro milênio. São Paulo: Casa do Psicólogo.

Smith, J. Z., \& Perry-Jenkins, M. (2012). The division of labor in lesbian, gay, and heterosexual new adoptive parents. Journal of Marriage and Family, 74, 812-828.

Stevens, E. (2015). Understanding discursive barriers to involved fatherhood: The case of Australian stay-at-home fathers. Journal of Family Studies, 21(1), 22-37.

Tiitinen, S., \& Ruusuvuori, J. (2015). Producing gendered parenthood in child health clinics. Discourse \& Society, 26(1), 113-132.

Trifan, T. A., Stattin, H., \& Tilton-Weaver, L. (2014). Have authoritarian parenting practices and roles changed in the last 50 years? Journal of Marriage and Family, 76, 744-761.

Viala, E. S. (2011). Contemporary family life: A joint venture with contradictions. Nordic Psychology, 63(2), 68-87.

Zvara, B. J., Schoppe-Sullivan, S. J., \& Dush, C. K. (2013). Fathers' involvement in child health care: associations with prenatal involvement, parents' beliefs, and maternal gatekeeping. Family Relations, 62, 649-661. 